\title{
Islamists and Nationalists: Rebel Motivation and Counterinsurgency in Russia's North Caucasus
}

\author{
Monica Duffy Toft, University of Oxford \\ Yuri M. Zhukov, University of Michigan ${ }^{1}$
}

\section{American Political Science Review (forthcoming) accepted 3 December 2014}

\begin{abstract}
This article offers the first disaggregated, quantitative comparison of Islamist and nationalist violence, using new data from Russia's North Caucasus. We find that violence by Islamist groups is less sensitive to government coercion than violence by nationalist groups. Selective counterinsurgency tactics outperform indiscriminate force in suppressing attacks by nationalists, but not Islamists. We attribute this finding to rebels' support structure. Because Islamist insurgents rely less on local support than nationalists, they are able to maintain operations even where it is relatively costly for the local population to support them. These findings have potentially significant implications for other contemporary conflicts, in which governments face both types of challenges to their authority and existing political order.
\end{abstract}

${ }^{1}$ Authors' names are listed alphabetically. Monica Duffy Toft is Professor of Government and Public Policy, Blavatnik School of Government, University of Oxford (monica.toft@bsg.ox.ac.uk). 10 Merton Street, Oxford, UK OX1 4JJ. Yuri M. Zhukov is Assistant Professor of Political Science and Faculty Associate at the Center for Political Studies, University of Michigan (zhukov@umich.edu), 5700 Haven Hall, 505 South State Street, Ann Arbor, MI 48109-1045. For helpful comments on earlier drafts, we are grateful to Ivan Arreguín-Toft, Jeffrey A. Friedman, Ron Hassner, Thomas Hegghammer, Seth Jones, Assaf Moghadam, Rich Nielsen, Jacob Shapiro, Robert Pape, Arthur Stein, Elisabeth Wood, four anonymous reviewers, and workshop participants at the University of Chicago, Harvard, Oxford, Princeton, RAND, and Yale. 
Are Islamist insurgencies more difficult for governments to coerce than nationalist ones? Recent violence by Salafi-Jihadi² groups in Afghanistan, Libya, Mali, Nigeria, Somalia, Thailand and, most recently, the Islamic State in Iraq and Syria, have renewed questions about the challengers modern governments face, and how they respond to coercion. Similar questions have emerged before. The rise of nationalism in 19th Century Europe prompted concerns that conflicts over national independence and self-determination might overturn the nascent system of states. Since then, and particularly since World War II, scholars have credited nationalism - an "imagined community" with a passionate attachment to land (Anderson 1991; Toft 2003) - with mobilizing combatants to fight even when doing so is very costly (Brown, et al. 1997; Lake and Rothchild 1998; Varshney 2003).

Although nationalism and religion seldom stand alone as motivations for insurgency, they potentially shape the nature of violence on the ground and call for different government responses. Conventional wisdom holds that selective government violence is more effective than indiscriminate violence in reducing rebel activity, since rebel supporters face a higher probability of punishment. Whether selective incentives have the same effect on violence by different types of groups is an open empirical question.

The effects of religious motivations on political violence remain largely unexplored. Of 9,541 books and journal articles about civil or interstate conflict published in the last decade, only 7 percent mention religion or Islam. ${ }^{3}$ Although scholars have long recognized that "identity matters" in war (Sambanis 2001), the most widely cited works of recent years have downplayed the role of identity in the onset of war (Fearon \& Laitin 2003; Collier \& Hoeffler 2004), and the tactics armed groups adopt (Pape 2005). A small but growing literature has begun to examine the role of religion more directly - in civil conflict (Hassner 2003; Hegghammer 2010/11, 2013; Toft 2007), interstate war (Horowitz 2009; Hassner and Horowitz 2010), and suicide terrorism (Bloom 2005; Hoffman 1998; Moghadam 2008, 2008/09; Pape 2005; Sageman 2004; Stern 2003; Bueno De Mesquita 2005; Asal \& Rethemeyer 2008). Much of this literature has debated whether tra-

2 "Salafi-Jihadi" denotes a branch of militant Sunni activism that adheres to the conservative Salafiyya movement, and is engaged in an armed struggle against what they deem "apostate" Muslim regimes or "infidel" non-Muslim governments and occupying forces. Although the terms differ in meaning and scope, we use "Salafi-Jihadi," "jihadi" and "Islamist" interchangeably here.

3 Statistics are based on a search of the Social Science Citation Index and Book Citation Index Social Science and Humanities from 2003 to 2014, using the queries ("civil war" OR "interstate war" OR "civil conflict" OR insurgency OR terrorism) and ("religion" OR "religious" OR "islam" OR "islamist" OR "jihad" OR "salafi"). 
ditional rational choice models can explain certain forms of religious violence, like suicide attacks (Berman \& Laitin 2008; Wintrobe 2003; Iannaccone \& Berman 2007; Juergensmeyer 2000; Caplan 2006).

The existing debate has been at once too narrow (focusing on only one set of tactics), and too broad (focusing on behavior not unique to religious groups). Suicide terrorism is an important but rare and extreme subset of organized religious violence. Moreover, groups with secular ideologies, like ethnic nationalism, also display dramatic self-sacrifice. No empirical studies, to our knowledge, have examined whether Salafi-Jihadi groups behave differently on the battlefield, or are more resilient in the face of government coercion. Empirical assessment of the "religion effect" has been mostly cross-national (Hegghammer 2010/2011) - an approach essential to uncovering variation across conflicts and states, but inadequate for studying variation in military conduct across and within rebel groups. We currently lack a commonly accepted operational definition of what "Islamist" violence is, or how one might discern religious motivation from violent action. As a result, we are unable to establish even how prevalent this type of violence has been.

This empirical gap is significant for theory and policy. An emerging consensus in the scholarly literature holds that indiscriminate violence is "at best ineffective and at worst counterproductive" (Kalyvas 2006, 151; Mason and Krane 1989). The logic of coercion requires punishment to be selective - conditional on a target's behavior. If supporting the rebels invites punishment, then not supporting rebels should prevent punishment. Where this is not the case and targets are chosen by collective rather than individual criteria (e.g. where one lives, rather than what one did), violence fails to generate strong lessons for future behavior. If Islamist rebels do not respond to selective incentives in this way, governments fighting them may see less reason to avoid crude-but-cheap indiscriminate violence.

Using new data from Russia's North Caucasus, we find that Islamist and nationalist rebels respond differently to coercion. While selective tactics outperform indiscriminate ones in eliciting compliance from nationalist rebels, the type of government violence has little effect on the resolve and capabilities of Islamists. We attribute this finding to the differential structure of rebel social bases, particularly their relative dependence on local versus external sources of support. By offsetting local support with revenue and manpower from elsewhere, Islamists can continue fighting even where the population faces heavy penalties for supporting them. This is not the case for nationalist insurgents.

Compared to violence by nationalist forces, Islamist violence is also more geographically dispersed, ebbs and flows with key dates on the Islamic calendar, and 
more closely mirrors international trends in jihadist violence. Otherwise, the determinants of Islamist and nationalist violence are largely the same.

Finally, we find that Islamist violence - even under the most expansive definition - represents only a minor share of violence in the Caucasus (3 to 19 percent). Even if selective violence were ineffective against Islamists, it is dangerous to extrapolate the same lesson to the region. If the overwhelming majority of a government's armed opponents are not jihadists, indiscriminate tactics will make it more difficult to persuade insurgents to lay down their arms.

\section{RELIGION, RATIONALITY AND VIOLENCE}

The term "religious violence" encompasses a broad range of actors and beliefs. We limit our current inquiry to Salafi-Jihadis - adherents to a strict interpretation of Sunni Islamic scripture, which rejects all civil law and institutions of the nation state, in favor of the absolute enforcement of God's sovereignty (hakimiyyah) over the earth, and the emulation of the behavior and practices of early Muslims (salaf). Where Salafi-Jihadis depart from ordinary Salafis is in their embrace of violence, particularly against non-believers (kafir) and "apostate" Muslims (murtadd) who have either left the religion or differ in their interpretation of Islam.

Violence by Salafi-Jihadi groups has risen sharply in recent decades, especially compared to violence by secular nationalists and mainstream Islamists (Moghadam 2008/2009: 70). Salafi-Jihadi organizations like Al Qaeda, the Islamic State and al Shabab have been primary targets of recent U.S.-led military operations, and are parties to dozens of civil conflicts from Asia to Africa. These trends are worrisome in light of recent evidence that religious civil wars - where at least one combatant fought to establish the primacy of a religious tradition in public life - are costlier, longer, and more likely to recur than other types of conflicts (Toft 2007). 4

Anecdotal reports suggest that Salafi-Jihadis may fight differently from other combatants, and are potentially more willing to accept losses. 5 If true, this characteristic of Salafi-Jihadi violence would seem to chip away at bargaining and selfpreservation, two pillars in our understanding of coercion. In situations where sec-

4 Non-religious civil wars last on average 92 months; religious civil wars last 114 months - almost two years longer (Toft 2007).

5 For example, in October 2014, U.S. intelligence officials reported that air strikes against the Islamic State had not reduced the flow of foreign fighters into Syria (Miller, 2014). 
ular actors can be compelled or deterred by the threat of destruction, Salafi-Jihadis may be content to sacrifice their lives (Toft 2007).

Two sets of explanations for these patterns have emerged. The first is that some religious beliefs - like afterlife rewards and divine audiences - may alter the payoffs actors assign to various outcomes. Caplan's (2006) model of "rational irrationality" allows actors to derive psychological and social benefits from fidelity to cherished beliefs, even if these beliefs are empirically unverifiable. Some Christian and Muslim traditions, for instance, expect self-sacrifice in religiously prescribed conduct to ensure eternal, super-physical existence in a heaven or paradise, offsetting the expected material costs of martyrdom (Toft 2007). In a similar vein, Juergensmeyer (2000) conceptualizes religious violence as a demonstration of obedience and loyalty to a "divine audience." This audience, in turn, provides an enforcement mechanism for altruism and self-sacrifice, making religiously motivated insurgents less sensitive to coercive pressure.

Beliefs may also explain the timing of violence. As Hassner (2011, 496-497) notes, religious holidays entail date-specific rituals and prohibitions, allowing believers to "communicate with the divine, and to receive divine favors." By synchronizing attacks with "sacred dates" on a religious calendar, combatants can signal knowledge and commitment to faith, bask in the reflected glory of historical battles, or amplify sectarian divisions. Because different dates carry different meanings for different actors, holiday-specific increases in violence should vary across groups. Islamist groups should rally around Islamic holidays, but nationalists should not.

A second view is that economic factors - rather than religious beliefs - dominate decision-making (Iannaccone \& Berman 2007). Wintrobe (2003) argues that divine audiences are insufficient to explain "self-destructive" acts of violence, since an omnipotent God cannot credibly commit to distributing afterlife rewards to martyrs (Wintrobe 2003). Alternative explanations include threats against defectors' family members, payments to martyred jihadists' kin (Berman \& Laitin, 2008), and utility gained from providing public goods to future generations (Azam, 2005). Spikes during religious holidays may result from reduced opportunity costs of rebellion during time off from work (Becker 1974), or reduced fighting costs due to seasonal shifts in weather. Because the same dates generate the same incentives for all rebels, holiday-specific changes in violence should be constant across different types of groups.

This debate has had two shortcomings. First, its scope has been mostly limited to suicide terrorism. While substantively important, suicide attacks represent a 
small proportion of terrorist violence worldwide, and terrorism itself is one of many tactics that insurgent groups use. Mainstream literature on civil wars and insurgencies, meanwhile, has been increasingly dismissive of the role of religion in armed conflict, with economic explanations claiming a dominant position in the field (Blattman \& Miguel 2010).

A related problem is that many of the supposed peculiarities of religious violence are not unique to religious conflicts. There is no shortage of self-sacrifice in secular national self-determination movements, as evidenced by the Filipino revolutionary José Rizal, Tamil Tiger suicide bombers, and Jan Palach' self-immolation during the Prague Spring. Nationalists also share the concept of sacred time - pro-Russian separatist groups in Ukraine, for instance, have escalated operations around dates commemorating Soviet victories in World War II.

These shortcomings limit our understanding of insurgencies like the Islamic State and Caucasus Emirate. Unlike conspiratorial terrorist cells, insurgencies directly challenge government forces through a campaign of sustained organized violence, and require active or tacit popular support to maintain their operations. Insurgencies also invite a different government response - a counterinsurgency emphasis on deterring a population from supporting rebels, rather than a counterterrorism emphasis on detecting and preventing attacks.

\section{COERCION AND THE REBEL SUPPORT BASE}

We argue that rebels' sensitivity to coercion depends on their relative reliance on local versus external sources of support. Because Salafi-Jihadi groups have greater access to outside resources due to their trans-national and trans-regional ties, they can maintain operations even if it is very costly for the local population to aid them.

The reliance of Salafi-Jihadi groups on external support is well documented (Sageman 2004; Hoffman 2006; Moghadam 2008). Although nationalists often rely on material and political support from an ethnic diaspora, Salafi-Jihadis define their goals in terms that transcend ethnic and state boundaries. ${ }^{6}$ The scope of Salafi-Jihadi goals - a rejection of modernity and Western materialism, the overthrow of "apostate" and "infidel" governments, and the reestablishment of an Islamic Caliphate - has facilitated inter-regional and transnational cooperation and emulation. Such appeals allow Islamists to extend their potential base beyond a

6 Many Salafis see borders between Muslims as illegitimate. As one Salafi scholar explained, "The house of Islam is one, and the legal rulings are one. This map that was imposed by Sykes-Picot and imposed by the Western occupation is of no consideration legally" (Al Jazeera, 2013). 
single diaspora, raise the visibility of their conflict, and mobilize support through international networks of jihadist newsletters and websites, imams, charities and support organizations. ${ }^{7}$ As a result, seemingly isolated incidents of violence can aggregate into discernible and deliberate global patterns, even without a centralized command structure or direct organizational links. ${ }^{8}$ Indeed, this was the original vision of Abdullah Azzam, the late co-founder of Al Qaeda, who sought to build a transnational jihadist infrastructure after the Soviet war in Afghanistan.

Because Islamist rebels have a more geographically dispersed social base than nationalists, a smaller share of their supporters (i.e. those living within a conflict zone) is directly exposed to government punishment. Targeted killings and arrests in a small community may compel local civilians to keep their heads down, but are less likely to deter an aspiring foreign jihadist from purchasing a plane ticket or an internet user from making a donation. Violence persists so long as external support keeps flowing.

By way of illustration, imagine a conflict zone inhabited by three groups of actors: rebels, government and civilians. The government and rebels both seek a monopoly on the legitimate use of force, which requires public support - in the form of taxes, manpower, intelligence and other resources needed to maintain military operations and build a viable state. ${ }^{9}$ At a minimum, both combatants want to prevent this support from reaching their opponents. They pursue this goal through coercion - punishing "bad" behavior, thereby making cooperation with opponents more costly. Civilians seek security, and will not support a combatant if the costs of doing so are too high. Selective violence implies that one will be punished if and only if one supports the opponent. Indiscriminate violence implies that punishment may come regardless of what the individual does. If the combatants rely only on local support, the side that generates more selective violence should prevail. ${ }^{10}$

The existence of an external support base complicates this interaction. If a combatant does not depend exclusively on the local population, he can offset deficien-

7 The three groups that have attracted the most foreign fighters in Syria are all Salafi-Jihadi - Ahrar ash-Sham, Jabhat an-Nusra and the Islamic State (Barrett, 2014).

8 In private letters captured during the U.S. Special Forces raid in Abottabad, Pakistan in 2011, Bin Laden expressed frustration over his inability to control al Qaeda's many affiliates (Lahoud, et al., 2012).

9 We assume that all combatants are functionally similar, distinguished only by their relative dependence on local versus external sources of support.

10 This model attributes a decline in violence to reduced capacity, rather than strategy change. Combatants face incentives to escalate in response to selective violence, and "out-coerce" the opponent. Violence would only decline if coercion deters civilians from providing support. 
cies in local support with revenues and manpower from elsewhere. Selective punishment may deter local civilians from supporting the opponent, but cannot prevent outside actors from doing the same. For rebels, the ability to mobilize capital and labor from foreign governments, charities and individuals offers a stream of resources that local policing will find difficult to interdict.

A diversified support base reduces vulnerability to coercion, but also generates incentives to escalate. With sufficient external support, a combatant no longer needs to persuade locals to cooperate, and a selective violence advantage becomes unnecessary. ${ }^{11}$ For his opponent - who must ensure not only that it is more costly to cooperate with the enemy, but that it is costlier by a significant margin - selective violence may become insufficient.

This interaction has several empirical implications. First, selective violence should be more effective in suppressing nationalist violence than Islamist violence. The logic here is purely structural: (1) selective violence deters the population from supporting rebels; (2) without popular support, rebels are unable to continue fighting; (3) Islamist rebels are less dependent on the local population than nationalists; (4) therefore, selective government violence should impact Islamist violence less than nationalist violence.

External support can also explain the trans-regional and trans-national dynamics of Islamist violence. To attract support from outside the immediate conflict zone, rebels forge alliances with actors in other theaters, exchanging personnel, information about best practices, praising the martyrdom of their "brothers," and assessing the policy responses of foreign governments. ${ }^{12}$ As Salafi-Jihadi groups make common cause with comrades in other regions and states, their violence becomes less geographically contained, and more responsive to outside events.

Differences in support structure also offer an alternative explanation for violence on religious holidays. Holidays alleviate some rebel collective action problems by providing occasions for the faithful to assemble and interact with one another. Yet because Islamists and nationalists have different bases of support, which may attach disparate meanings and hierarchies to different dates, we would expect the "holiday effect" to be heterogeneous across groups - with nationalist violence spiking on nationalist holidays, and religious violence on religious holidays.

11 The logic here is similar to Weinstein's (2007: 9-11) proposition that resource-rich groups are less likely to seek cooperative bargains with non-combatant populations.

12 On September 23, 2014, for instance, Kavkaz Center (@kavkazcentercom) tweeted, “Al Shabaab’s attacks on Kenya working. Majority of Kenyans demand Kenya army withdrawal from Somalia.” 


\section{ISLAM AND INSURGENCY IN THE NORTH CAUCASUS}

In Russia's North Caucasus, nationalist and religious rebels have co-existed for over 15 years, fighting the same enemy, over the same terrain, at roughly the same time. The main nationalist group has been the largely secular Armed Forces of the Chechen Republic of Ichkeria (ChRI), which fought a victorious separatist war against the Russian Federation in 1994-1996, and an unsuccessful one after 1999. The region's Salafi-Jihadi religious organizations include groups that at various points were at least nominally subordinate to ChRI (e.g. ChRI's Sharia Guard, Arab Mujahedeen) and others that were either founded outside ChRI's command structure, or have since expanded their objective from independence to a revolutionary Islamic state (e.g. Islamic International Peacekeeping Brigade (IMMB), Caucasus Front, Caucasus Emirate and smaller dzhamaats (communities)).

These groups have similar tactics and targets, but - following a nationalistIslamist split within Chechnya in 1996-97 - have pursued different goals. ${ }^{13}$ ChRI's late president Aslan Maskhadov saw the insurgency's mission as national liberation, declaring, "Chechens have but one request - that we be left alone" (Kavkazskiy Uzel, 2003). As is typical of a national self-determination struggle, their fight has been circumscribed and defensive (Toft 2003). In contrast, the Caucasus Emirate's founder Doku Umarov sought a potentially transnational Islamic state: "I reject all kafir laws established in the world... I reject all names used by infidels to divide Muslims... After expelling the kuffar we must re-conquer all historical lands of Muslims, and these borders are beyond the boundaries of Caucasus" (Press Office of the Amir of the Caucasus Emirate, 2007). Their fight has been expansive and offensive.

To a greater extent than nationalists, religious groups have attracted recruits from states and regions outside Chechnya, including up to 600-700 foreign fighters (Zaitsev, 2011) and prominent Russian converts like Said Buryatskiy and Pavel Kosolapov. While Maskhadov actively opposed non-Chechen recruits, declaring "Arabs, Tajiks and other vagrants have no business here," Islamist field commanders like Shamil Basaev called on other "nations in bondage... to understand the necessity of unified liberation" (KavkazCenter.com, 2012).

This differential reliance on external support reflects inherent recruitment challenges in the Caucasus. The "pure Islam" of Salafism has historically been at odds with the region's more heterodox local customs, ranging from Sufi brotherhoods

13 Almost all Caucasus groups employ guerrilla tactics like ambushes, bombings and hit-and-run attacks, against hardened military targets and civilians. 
(tarikat) and tribal justice institutions (adat) to the Hanafi school of Sunni jurisprudence (Malashenko 2001; Yarlykapov 2006). Maskhadov once joked that, "for wahhabi ideas to rise in Chechnya, it is necessary to first destroy all the Chechens" (Batuev, 1999). Indeed, Basaev saw reliance on local support as more of a liability than an asset: "we mujahideen should be self-sufficient and fight not for public support, but for the blessing of almighty Allah" (KavkazCenter.com, 2012).

Salafi groups have pursued this self-sufficiency through a novel organizational structure. While ChRI was effectively an alliance of traditional Chechen tribal institutions (teip and tukkhum), the Caucasus Emirate comprises a more diverse network of Salafi-Jihadi communities (dzhamaat), distributed across seven regions (vilayat) in nine provinces of southern Russia. Because dzhamaat membership is based on shared religious identities rather than common ancestry or geographic roots, these groups have been able to accommodate a more diverse pool of recruits, in locations where public support for Salafism has traditionally been low.

Statistics on these groups are notoriously unreliable. Unofficial estimates place the overall size of the Caucasus insurgency at 2,000-3,00o fighters throughout the conflict, with IMMB and other Salafi groups accounting for 13-20 percent of the force initially (IISS, 2002), and gradually rising. In 2009, the Prosecutor General's office estimated some 1,500 fighters in the Salafi Caucasus Emirate alone (Lenta, 2009). In the absence of better data, these figures are difficult to verify.

\section{A MICRO-LEVEL ANALYSIS}

Do Islamist rebels behave differently on the battlefield than secular rebels? We can answer "yes" if Islamists attack under different conditions than nationalists, and if Islamist rebels respond differently to government coercion.

Using a new dataset of Islamist and nationalist violence in the North Caucasus, we track weekly patterns of violence across 7,584 towns and villages in 200 districts (rayons) in nine provinces of southern Russia between 2000 and 2012. ${ }^{14}$ Due to its diversity of actors, tactics and ethnic, geographic, demographic and socioeconomic conditions, the North Caucasus case enables us to account for many potentially confounding structural factors.

Islamist violence is a difficult concept to operationalize. Individual acts of violence are observable, but the motivations behind them are usually not. Certain in-

14 These provinces include the republics of Adygea, Chechnya, Dagestan, Ingushetia, KabardinoBalkaria, Karachaevo-Cherkessia, and North Ossetia, and the majority-Russian regions of Krasnodar and Stavropol. The date range excludes conventional operations in 1999 and early 2000. 
cidents have an unambiguously religious, even puritanical character, like attacks against moderate Sufi clerics, or against institutions that sell alcohol. Others are more ambiguous, like attacks by groups using religious rhetoric and symbols in service of a wider movement of national liberation. We accounted for this uncertainty by using multiple definitions of Islamist violence, from very broad to quite narrow. If our results are consistent across these definitions, we can have more confidence in their validity. Using a triadic framework, we disaggregated insurgent attacks by group affiliation, tactics used, and targets attacked. We then constructed a four-tiered typology of Islamist violence: (1) expansive; (2) intermediate; (3) limited; and (4) target-based. We provide a brief description of this typology below, and a more detailed discussion, with specific actor-tactic-target mappings and illustrative examples, in the appendix and online supplement. ${ }^{15}$ Figure 1 offers a graphical representation.

\section{[FIGURE 1]}

The expansive definition of Islamist violence includes the broadest array of actors: any armed groups with expressed Salafi-Jihadi objectives, "Wahhabis" (selfidentified, or so described by officials or reporters), "black widows" (female suicide bombers), dzhamaats, charities and clerical elites. Any use of force by any of these actors, against any government or civilian target, classifies as an Islamist attack.

The intermediate definition includes only those groups explicitly seeking to establish an Islamic state through force. This includes ChRI's autonomous Islamic units, Arab mujahedeen, Caucasus Front, Caucasus Emirate and its dzhamaats.

In the Caucasus as elsewhere, the boundary between jihadis and nationalists is nebulous. The expansive and intermediate definitions treat actions by Islamic units of otherwise secular movements, like the ChRI Sharia Guard, as Islamist rather than nationalist incidents. The limited definition treats such cases as nationalist rather than Islamist.

The target-based definition is the most restrictive. An attack's targets must be institutions deemed forbidden, impure or otherwise foreign according to Salafi interpretation of scripture (e.g. liquor stores, discotheques). This category might be considered religious vigilantism, where perpetrators are seeking to rectify a perceived moral turpitude.

Finally, nationalist violence may involve any group affiliated with ChRI leadership and armed forces, employing guerrilla tactics against government or civilian actors. We treated nationalist and Islamist violence as mutually exclusive across 
this four-tiered typology. As specified in the appendix, the nationalist label excludes violence by groups with mixed separatist-religious objectives under the expansive and intermediate definitions, but includes them under the limited and target-based definitions.

Applying this typology of violence requires micro-level data capable of faithfully reflecting our conceptual quantities of interest. Despite the increasing availability of disaggregated data on the North Caucasus (see O'Loughlin, et al. 2011; Toft \& Zhukov, 2012; Zhukov, 2012), few preexisting resources are available for this purpose. We created a new dataset from incident reports collected by the Russia-based human rights nongovernmental organization, Memorial society. Memorial's Hronika nasilija [Chronicle of Violence] records dates, locations, participants, casualties, and other details of violent incidents in the Caucasus, 2000-2012. Mitigating some of the reporting biases associated with single-source data, Memorial draws on information from independent human rights organizations and NGOs (26.5 percent), state-owned wire services (25 percent), private wire services (19.9 percent), private newspapers and broadcast media (14.3 percent), government agencies (12.6 percent), and international news sources (1.7 percent).

In all, our data include 43,336 unique events recorded between July 2000 and March 2012, representing the most comprehensive sample of state and nonstate violence in Russia that open sources currently permit. These include 9,405 incidents of rebel-initiated violence and 22,573 incidents of government-initiated violence. We geo-coded these events with fuzzy string matching against the GeoNames database, and aggregated them to the unit of a district-week. Rather than rely on off-the-shelf coding dictionaries typically used for event data extraction, we developed a custom dictionary in Russian based on an actor-action-target framework that corresponds directly to the categories described in Figure 1 and the appendix.

Before proceeding to our main analysis of Islamist military conduct and responsiveness to coercion, we present an overview of general patterns in the data.

Islamist violence is relatively infrequent

As Table 1 shows, Islamist groups account for 3 to 19 percent of insurgent violence in the North Caucasus in 2000-2012. Even under the broadest definition, SalafiJihadi violence represents a minority of political unrest in the region, well behind that perpetrated by nationalist groups ( 67 to 75 percent), and violence we were unable to attribute to either category, such as blood feuds and organized crime (15 to 23 percent).

[TABLE 1] 


\section{But Islamist violence has become more common}

Due in part to a decrease in nationalist activity, Islamist groups have claimed a progressively larger share of violence over time. We show this trend in Figure 2, where points represent weekly incident counts of nationalist and Islamist violence and smoothed lines represent six-month moving averages.

[FIGURE 2]

By the limited, intermediate and extensive definitions, Islamist groups generated 3 to 10 percent of all non-state violence in 2000, and 13 to 31 percent in 2011. In relative terms, the ratio of Islamist-to-nationalist attacks has increased fourfold. Under the "target-based" definition, however, the proportion remained at 1-3 percent over the full period, apart from a spike to 7 percent in 2006.

\section{Islamist violence is more geographically dispersed than nationalist violence}

Our data further show that Islamist violence is more geographically dispersed than nationalist violence, consistent with what we would expect of groups with a more distributed support base. Figure 3 a reports the proportion of Islamist or nationalist attacks by province. While Chechnya bore the majority of nationalist violence in 2000-2012, most Islamist attacks occurred outside Chechnya's borders.

[FIGURE 3]

Figure $3 \mathrm{~b}$ shows the same proportions by the dominant ethnic group of a targeted village. Majority Chechen villages witnessed most nationalist attacks, but a majority of Islamist attacks occurred in non-Chechen villages: in settlements dominated by Russians (17 percent), Ingush (13 percent) and others.

[TABLE 2]

Table 2 reports a third measure of dispersion: the average road distance, in kilometers, from the location of an insurgent attack to the nearest village where an attack of the same type occurred the previous week. The average distance is 126 to $494 \mathrm{~km}$ for Islamist rebels, but just 50 to $52 \mathrm{~km}$ for nationalists. These patterns suggest that nationalist insurgents circumscribe their fight to a tighter geographical space, focusing on relatively localized campaigns. Islamist violence, however, unfolds over a much broader expanse.

Islamist attacks more closely reflect global trends in suicide terrorism

As we would expect of groups with ideological or aspirational ties to the global jihad movement, Islamist violence is more sensitive to events occurring beyond Russia's borders. Table 3 reports the percent increase in local insurgent attacks on 
weeks with higher-than average levels of suicide terrorism outside Russia. ${ }^{16}$ This increase is up to three times higher for Islamists than nationalists (78-93 percent to 29-35 percent). Though hardly evidence of formal coordination, this pattern suggests that the region's Islamists are more likely to emulate or show solidarity with outside groups.

\section{[TABLE 3]}

\section{Islamist violence spikes on religious holidays}

We find strong evidence that the religious calendar correlates with Islamist activity. Table 4 reports the percent increase in insurgent violence on Islamic holidays. ${ }^{17}$ The more narrow the definition of Islamist violence, the stronger this relationship seems. Under the expansive definition, Islamist violence is 11 percent higher on Muslim holidays; under the target-based definition, it is 73 percent higher. For nationalist violence, this increase is 3-4 percent. Chechen nationalist holidays, meanwhile, yield no change in Islamist violence, but a sizable uptick in nationalist attacks. ${ }^{18}$ This finding challenges both the opportunity-cost and seasonality views of rebel violence - if the "holiday effect" were driven primarily by an increase in spare time or by favorable fighting conditions (Ramadan occurred in the autumn in the 2000's), we would expect the same calendar to affect both types of groups equally. Yet our data show that - in a region that celebrates both sets of holidays - Islamist and nationalist attacks occur on around different dates.

[TABLE 4]

\section{Islamist insurgents are less susceptible to coercion}

Most significantly, the data suggest that Islamist insurgents may be more difficult to coerce. To ascertain insurgents' sensitivity to coercion, we distinguished between two types of government violence: (1) selective, where targets were chosen on the basis of individual attributes, like partisan affiliation with an insurgent group; and (2) indiscriminate, where targets were chosen on some collective crite-

16 Formally, the quantity is $100^{*}(\mathrm{E}[Y \mid X>\bar{x}] / \mathrm{E}[\mathrm{Y} \mid \mathrm{X}<\bar{x}]-1)$, where $\mathrm{Y}$ is the number of insurgent attacks in a district-week, and $\mathrm{X}$ is the number of global suicide terrorist attacks that week (excluding Russia).

17 Formally, the quantity is $100^{*}(\mathrm{E}[Y \mid X=1] / \mathrm{E}[Y \mid X=0]-1)$, where $Y$ is the number of insurgent attacks in a district-week, and $X$ is 1 if the week falls on any of the following holidays: Al-Hijra, Laylat al-Qadr, Mawlid an Nabi, Isra and Mi'raj, Ramadan, Eid ul-Fitr, Arafat Day, Eid al-Adha.

18 Official ChRI holidays include Tolaman denosh (Victory Day), Day of Chechen National Rebirth (Deportation), ChRI Constitution Day, Glazotan de (Shahid Memorial Day), War's End Day, Caucasian Rebirth Day, Jihad Day, Independence Day, and Russian Withdrawal Day. 
rion, like ethnicity or location. Selective violence includes arrests, targeted killings and kidnappings. Indiscriminate violence includes artillery barrages, cordon-andsearch operations ("mop-ups"), and aerial bombardment. We assume coercive leverage to be greater in the selective case because, as Schelling $(1966,2)$ notes, "to be coercive, violence has to be anticipated. And it has to be avoidable by accommodation." Indiscriminate detentions and artillery fire do not meet this standard, since compliance (i.e. staying neutral) may not provide immunity from harm.

Table 5 reports the relative effectiveness of selective and indiscriminate counterinsurgency tactics in suppressing insurgent violence. ${ }^{19}$ In the twelve weeks following a counterinsurgency operation, districts where government forces employed only selective tactics saw 54-55 percent fewer nationalist attacks than those subjected to indiscriminate tactics. The effect on Islamist violence was weaker, with an average decrease of $37-44$ percent.

[TABLE 5]

Although this difference is highly significant, it should be interpreted with caution. Russian security forces do not select tactics randomly. Selective violence requires human intelligence, which in turn requires the protection of informants from retaliation. Indiscriminate force, meanwhile, does not require detailed, localized information on the enemy's identity and whereabouts. As a result, we might expect selective violence where some modicum of state control already exists (Kalyvas 2006), and any subsequent security improvements may be consequences of this selection process. Indeed, 63 percent of Russian counterinsurgency operations since 2000 relied on indiscriminate tactics, while just 37 percent involved only selective tactics. To address this and other barriers to inference, we ran a series of more rigorous tests.

\section{DETERMINANTS OF ISLAMIST VIOLENCE}

We now present model-based predictions of Islamist and nationalist violence under several counterfactual scenarios, controlling for geography, demographics, ethnicity, historical grievances, and recent levels of violence in neighboring districts. ${ }^{20}$ We adopt the intermediate definition of Islamist violence here (i.e. only the

19 Formally, the quantity is $100^{*}(\mathrm{E}[Y \mid X=$ selective $] / \mathrm{E}[Y \mid X=$ indiscriminate $]-1)$, where $Y$ is the number of insurgent attacks in a district in the twelve weeks following a counterinsurgency operation, and $X$ denotes whether counterinsurgency tactics were selective or indiscriminate.

20 The simulations in Table 6 are based on a spatio-temporal autologistic model of Islamist (or nationalist) violence in a district/week, with the covariates: global suicide terrorist incidents per 
armed groups explicitly seeking to establish an Islamic state) but provide results for other definitions in the online supplement.

[FIGURE 4]

The quantities in Figure 4 can be interpreted as: "How much more (less) likely would an insurgent attack be under the stated counterfactual scenario, all else equal?" ${ }_{21}$ For example, the first line of Figure 4 says an Islamist attack will be 200 percent more likely in a week with a high level of global suicide terrorism (12 attacks, or 99th percentile) than in a week with little suicide terrorism outside Russia (o attacks, or 1st percentile).

In almost all counterfactual scenarios, the relative risks of Islamist and nationalist violence move in the same direction, suggesting that the core drivers of violence are the same for both groups. A key exception is in the timing of violence. Muslim holidays increase the probability of an Islamist attack by 20 percent, but do not influence nationalist violence. Chechen nationalist holidays raise the probability of nationalist violence by 9 percent, but have no effect on Islamist attacks.

Most of the remaining distinctions can be attributed to differences in the support structure of Islamist and nationalist rebels, and differential patterns of coordination with local and external actors. For instance, Islamist attacks exhibit a stronger covariance with global suicide terrorism, but a weaker relationship with violence in neighboring districts. Nationalist violence, meanwhile, is more strongly influenced by events in the immediate vicinity. Most other counterfactuals yield variation within the categories of rebel violence, but not between them.

week, Muslim holidays, Chechen nationalist holidays, distance from nearest military base, population density, elevation, slope, distance from nearest refugee camp, distance to nearest international border crossing, percent Russian speakers, proportion of villages deported in 1944, and percent forest cover. In addition, we estimated (1) a logit model with district-level random effects, predicting the incidence of Islamist (or nationalist) violence in a district/week, (2) same specification with district-level fixed effects, (3) same with a rare-events correction, (4) a hurdle model that simultaneously predicts the incidence and severity of violence, and (5) a bivariate probit model that corrects for simultaneous interdependence between Islamist and nationalist attacks. These analyses - included in the online supplement along with a more detailed technical discussion - confirm the results reported here.

21 Formally, the quantities in Table 8 are $100^{*}\left(\mathrm{E}\left[Y \mid X=x_{1}\right] / \mathrm{E}\left[Y \mid X=x_{0}\right]-1\right)$, where $x_{1}, x_{\mathrm{o}}$ are counterfactual values of variable $X$ (i.e. change from $X=x_{0}$ to $X=x_{1}$ ), and all other covariates are held constant at their median values. 


\section{RESPONSES TO COUNTERINSURGENCY}

The most consequential difference between Islamist and nationalist violence is the effectiveness of the Russian government's counterinsurgency operations. Our first look at the data indicated that Islamists are potentially less responsive to coercion than nationalists. Yet a bivariate cross-tabulation cannot account for the multiple confounding factors that might also drive this result, including the possibility that counterinsurgents use selective tactics where violence is already low.

To facilitate a more rigorous evaluation of counterinsurgency practices, we used matching to "pre-process" the 8,762 cases where Russian security forces (or their local proxies) conducted at least one counterinsurgency operation in a districtweek. ${ }^{22}$ We divided these cases into ones where the government employed only selective tactics like arrests, assassinations, kidnappings (3,259 cases), and ones where it employed indiscriminate methods like artillery shelling, aerial bombardment and cordon-and-search "mop-up" operations $(5,503) .{ }^{23}$ For each case of selective violence, we looked for the closest case where indiscriminate violence was used, but all other conditions - pre-existing levels of insurgent violence, terrain, demographics, location and other variables shown in Figure 4 - were nearly identical. ${ }^{24}$ To account for secular trends and seasonal fluctuations in fighting, we restricted all matched pairs to the same year, month and dates on the religious calendar. We then applied several matching algorithms to restrict our sample to only the most directly comparable cases of selective and indiscriminate violence. Due to space constraints, we analyze only the most conservative matched sample in these pages - where Russians used selective and indiscriminate violence under the most similar of circumstances. Other matching estimators confirm these results. ${ }^{25}$

22 We treated multiple operations in one district over one week as single observations.

23 We classified cases where Russian forces used both types of tactics as indiscriminate. The online supplement includes sensitivity analyses with alternate definitions of "selective tactics."

24 Formally, we matched treatment (selective) and comparison (indiscriminate) cases on all observable pre-treatment covariates, to ensure that treatment assignment (use of selective versus indiscriminate tactics) is ignorable, or independent of the outcome (subsequent level of insurgent violence) conditional on observable pre-treatment covariates. Matching estimators help us avoid excessive extrapolation in causal inference, reducing model dependence.

25 Matching algorithms included Mahalanobis distance, propensity scores, and coarsened exact matching (CEM). CEM produced the greatest improvement in balance (88 percent), with 829 treatment and 953 comparison cases. We discuss only the CEM results here, but provide others in the online supplement [LINK]. 
Figure 5 reports simulated changes in Islamist and nationalist violence, following a shift in counterinsurgency tactics. ${ }^{26}$ These quantities have the following interpretation: "How much more (less) prevalent would insurgent violence become if the government switched from indiscriminate to selective tactics, all else equal?”

[FIGURE 5]

The matched analysis confirms that selective counterinsurgency tactics are less effective against Islamists than nationalists. The expected number of Islamist attacks in the 12 weeks following selective violence is about the same as what an average district would experience after indiscriminate violence (about 2 percent lower, but with confidence intervals covering zero). The same statistic for nationalist attacks is substantively larger, at -5 percent, and statistically significant.

Nationalist insurgents were consistently and significantly more responsive to selective than indiscriminate tactics, even under the most onerous of tests. In the twelve weeks following a counterinsurgency operation involving only selective tactics, an average district saw between 1 and 9 percent fewer nationalist attacks than a similar district where indiscriminate tactics were used. By contrast, switching from indiscriminate to selective tactics produced only a small and highly uncertain reduction in Islamist violence.

\section{ILLUSTRATIVE EXAMPLES}

A closer look at some of the matched pairs from an early period in the conflict illustrates how this process unfolded in practice. ${ }^{27}$ On September 21, 2002, Saydar-Ali Ismailov was visiting relatives in Novye Atagi, a village in the Shali district of Chechnya. Home after three years of exile in Ingushetia, he was waiting at a bus stop across from the village's central Mosque. At 4:00 PM, an unmarked armored truck pulled up to the bus stop, and masked men sitting inside opened fire. When Ismailov fell to the ground, one of the men exited the vehicle and fired a "control shot" to his head. The truck then drove off, joined a convoy of military vehicles at the edge of town, and left the village through an army checkpoint.

In a similar incident earlier that month, masked men in an army van assassinated local resident Lechi Shaipov, when he was sitting on a bench with friends. A few

26 Formally, the quantities are percent increase in incidence, or $\left(\exp \left(\beta_{1}\right)-1\right) * 100 \%$, where $B_{1}$ is the negative binomial regression coefficient on the treatment variable (switch from indiscriminate to selective tactics).

27 The original text of these incident reports is available at http://www.memo.ru/hr/hotpoints/. 
days later, masked camouflaged men approached Sharpudi Dudaev while he was drinking tea in his neighbor's yard, asked his name, and shot him dead.

In each case, authorities had suspected the targets of cooperating with rebels. Locals attempting to pursue the assassins were stopped at army checkpoints, while the fleeing vehicles passed through unimpeded.

The assassinations in Shali at least had the appearance of selectivity. One individual was targeted each time, and bystanders were mostly unharmed. Even if the extrajudicial killings were based on poor intelligence, it appeared that the assassins were looking to punish a specific individual for a specific offense.

These targeted killings contrasted starkly with "mop-up" operations conducted the same month in nearby Urus-Martan, a district with similar size, terrain, demographics, ethnic composition, and prior levels of violence. ${ }^{28}$ Over the course of a week in Urus-Martan, government forces carried out daily "mop-ups," in which unmarked armored personnel carriers cordoned off a village or neighborhood, and masked men conducted house-to-house searches, indiscriminately detaining males of military age. Security forces rarely stated the reason for an arrest, or the facility in which detainees would be held. Only a third of known detainees were subsequently released; most were eventually labeled missing or dead (Memorial n.d.).

In the twelve weeks prior to the assassinations and mop-ups, the two districts had each experienced 2-3 attacks by forces loyal to the separatist Chechen Republic of Ichkeria, and one attack each by Islamist splinter factions like the Special Purpose Islamic Regiment and the International Islamic Brigade. ${ }^{29}$ In the twelve weeks following the government operations, nationalist violence stopped in Shali but persisted in mopped-up Urus Martan. Islamists, meanwhile, continued to attack Shali, despite the district's more selective policing practices.

This differential response to coercion reappeared throughout the conflict. Nationalist violence declined after a series of selective killings in Gudermes in April 2003, but persisted in Kurchaloy, an otherwise similar district where indiscriminate tactics were used at the same time. After July 2007, nationalist violence dropped in Ingushetia's Malgobek district following a spate of individual arrests,

28 Shali and Urus-Martan have, respectively, mean elevations of 213 and 235 meters, with average slopes of 0.79 and .68 degrees. Neither district has significant forest cover. Each district is within a half-hour's drive from the nearest military base, and an hour from the nearest refugee camp. Each district is home to 120,000-130,000 residents, 60 percent of whom speak Russian.

29 In the twelve weeks prior to the operations, Shali had experienced 4 rebel attacks and 17 government operations. For Urus-Martan, the same statistics were 3 and 22. Islamist rebels (intermediate definition) carried out one of the rebel attacks in each district. 
but grew in Urus-Martan, where mop-ups were used. In none of these cases did selective policing tactics suppress Islamist violence, or prevent it from escalating.

\section{ALTERNATIVE EXPLANATIONS}

Consistent with our theoretical expectations, Islamist insurgents in the Caucasus seem more resistant to coercion than nationalists. Support structure is, of course, only one potential explanation for this result. While a definitive test of other mechanisms lies beyond the scope of this article, we can offer some initial considerations about their plausibility given the data and our reading of the case.

\section{“ISLAMISTS ARE MORE EXPERIENCED FIGHTERS”}

One potential explanation for jihadis' resilience under coercion is combat experience. Staffed by more seasoned fighters, these groups may be more familiar with government policing practices, and more desensitized to coercive pressure than rag-tag local resistance units. As Figure 2 shows, Islamist violence became a potent force in the Caucasus largely after nationalist violence began to wane, which may have allowed Islamists to learn from their peers' mistakes.

This view finds little support in the data. To avoid comparing Islamists in 2011 to nationalists in 2001, we matched exactly on the year and month in which an operation took place. We also conducted additional analyses, with linear trends, yearly dummies and samples restricted to the peak of the conflict in 2004-2006, when both types of groups were highly active. These results, provided in the online supplement, are consistent with what we reported here. Even in the relatively narrow time period when nationalists were still ascendant, and Islamists groups had yet to coalesce into a robust regional network, selective tactics had a negative effect on nationalist violence, but no impact on Islamist violence.

\section{“ISLAMISTS FACE DIFFERENT COUNTERINSURGENTS"}

A related argument is that the type of government actors conducting counterinsurgency - more so than the type of rebels they fight - shape responses to coercion. Due in part to their informational advantage, we may expect local pro-government militias, often staffed by co-ethnics of the rebels, to employ more selective forms of violence than federal troops (Lyall 2010). If true, Islamist rebels may appear more resistant to selective violence because the actors employing that violence against them are bungling federal forces, rather than their more discriminating local allies. 
The data do not support this view. Islamists are indeed more likely to face federal forces than local authorities, but only because federal forces have been more active in counterinsurgency overall. Controlling for this relative frequency, local forces are actually 40 percent more likely than federal forces to operate where Islamist groups are highly active. $3^{\circ}$ When we compare operations by federal forces to ones by regional and municipal authorities, we find that local forces are slightly more effective overall. ${ }^{31}$ Yet where local and federal security forces are equally likely to operate, local forces perform better only against nationalists..$^{2}$

\section{[FIGURE 6]}

This result, shown in Figure 6, is consistent with our narrative. Local forces' superior local knowledge may give them an edge against locally-based nationalists, but not a jihadist network distributed across multiple jurisdictions. Even if local police or militia can deter their own populations from supporting Islamist groups, they are less likely to deter supporters outside their home district or province, or disrupt inter-regional flows of weapons, finances and personnel. At this task, local and federal forces are equally ineffective.

\section{“ISLAMISTS ARE IRRATIONAL”}

A more sweeping explanation for Islamists' muted reaction to selective violence is that they are somehow "less rational" than nationalists. The central empirical implication of the "irrational" argument is similar to ours: Islamist rebels should be more resistant to coercion. Yet if this pattern exists because Islamists are irrationally prone to errors and miscalculations, and nationalists are not, then we should observe systematic differences across the board in how the two types fight. Instead, we find substantial overlap in the drivers of nationalist and Islamist violence. As Figure 4 shows, most differences are ones of degree rather than kind. Whatever the relative prevalence of these "rationality-defying" traits, the data suggest that the two types of violence sit on the same continuum.

Moreover, the few disparities we do detect all point to our preferred mechanism. Islamists' sensitivity to global patterns of jihad, greater geographic dispersion, and

308.8 percent of local operations occurred in districts where Islamist violence had been more prevalent than nationalist violence in the past 12 weeks, compared to 6.2 percent for federal forces.

31 We report full results in the online supplement.

32 We used the same four matching algorithms as before, with propensity scores producing the greatest improvement in balance ( $85-88$ percent). We discuss only those results here, but provide others in the online supplement [LINK]. 
use of religious holidays as rallying points suggest inter-regional and transnational coordination and emulation, a wider battlefront, and a more diverse support base.

To the extent that selective violence deters civilians from supporting rebels, the latters' capacity will only decline if the rebels actually depend on the targeted population for support - as locally based nationalists surely do. If a greater share of the rebels' recruitment pool is from outside the targeted area - as appears to be the case with Islamists - a terrorized and war-weary population is insufficient to stop rebel operations.

\section{ISLAMIST VIOLENCE BEYOND THE CAUCASUS}

Salafi-Jihadism is an emerging force in international politics. In places like Iraq, Mali and Syria, Islamist rebel groups are currently fighting alongside nationalist and sectarian ones, much like they did in southern Russia. While our scope here was limited to Salafi-Jihadi and nationalist violence in the Caucasus, anecdotal evidence suggests that these groups' differential responses to government coercion may be part of a broader pattern.

IRAQ

Following the removal of Saddam Hussein from power in April 2003, several Iraqi nationalist and Salafi-Jihadi groups sought to expel American troops and unseat the transitional government. Nationalist groups like al-Awda and the Islamic Army in Iraq had few, if any, foreign fighters in their ranks, and drew support mainly from the local Sunni population and former members of the Hussein regime. Salafi-Jihadi groups like Ansar al-Islam and Al Qaeda in Iraq (AQI) saw the conflict as part of a global struggle against the United States, and drew more heavily on fighters from Libya, Saudi Arabia and Tunisia (Felter and Fishman 2007). Throughout the war, Sunni nationalists were more open to the political process, warning AQI not to attack polling stations, and - during the Sunni Awakening in 2007 - defecting en masse to the government in exchange for protection and private goods (White and Neuman 2005; Long 2008). AQI, meanwhile, remained hostile to reconciliation, and escalated its campaign in 2006 after a string of targeted killings gutted its command, including its leader Abu Musab al-Zarqawi. 


\section{MALI}

In 2012, the National Movement for the Liberation of Azawad (MNLA) took up arms against the Mali government to establish an independent Tuareg state, a struggle that had been ongoing since the 1960s. The Salafi-Jihadi groups Ansar Dine and the Movement for Oneness and Jihad in West Africa (MOJWA) joined the rebellion, seeking to impose Sharia Law throughout Mali. While the MNLA was largely homegrown, the Islamists received considerable support through jihadist networks in Europe and North Africa (International Crisis Group, 2013). Even in parts of Northern Mali where support for the MNLA was high, the Islamists had managed to assume territorial control by mid-2012. Under heavy pressure from all sides, the MNLA briefly realigned with the Mali government in late 2012 and signed a ceasefire agreement the following summer. Although short-lived, these overtures had no counterpart on the Islamist side, where jihadists refused to negotiate, even under heavy coercive pressure by Malian and French government forces.

SYRIA

The popular uprising in Syria has seen a similar split between secular groups seeking to overthrow the government of Bashar al-Assad, and Salafi-Jihadi groups seeking to establish an Islamic state. While all sides have received substantial external support, Islamist groups like Jabhat an-Nusra and the Islamic State have been particularly dependent on foreign fighters (International Crisis Group 2012). Some Islamist groups, like the Muhajireen Brigade - Chechen-led, and affiliated with the Caucasus Emirate - have been manned almost exclusively by non-Syrians. In all, an estimated 800 Russian citizens have joined foreign fighters in Syria, the largest contingent from any non-Arab country (Washington Post, 2014). The core of the secular Free Syrian Army (FSA), by contrast, originated with mostly-Sunni defectors from the Syrian Army. While elements of the FSA have supported the Geneva II peace conference, Islamic State and other jihadi groups have rejected negotiations, instead seeking to expand the war into neighboring states like Iraq.

These brief anecdotes are, of course, insufficient to establish resistance to coercion as a general Islamist trend. The secular groups in each case were more open to compromise than Islamists, but their relative power and influence had been declining for many reasons - coercive pressure being only one. Although a disaggregated, matched analysis of these conflicts would be needed to isolate this effect, the general patterns are consistent with what we found in the Caucasus. Less dependent 
on the support of the local population, Islamists are able to absorb more costs, and continue fighting where other groups might have stopped.

\section{CONCLUSION}

This article offered the first disaggregated, quantitative comparison of religious and nationalist violence, using new data from Russia's North Caucasus, where jihadi and nationalist insurgents have operated in the same region, time period, and against the same political opponents. We found that Islamist rebels differ from nationalists more in degree than kind, but important distinctions exist. In the Caucasus, Islamist violence has been more geographically dispersed, more aligned with global patterns of jihadist violence, and more likely to occur on religious holidays than nationalist violence. The most substantively important distinction pertains to government coercion. While selective counterinsurgency tactics are more successful than indiscriminate force in suppressing nationalist violence, they have little to no effect on Islamist violence.

These findings are significant because we currently lack an empirical basis to understand how religion shapes the conduct of war on the tactical level, and our article offers an important first step toward establishing such a basis. Yet the results also point to a troubling policy implication: the discriminate use of force works against nationalist rebels, but not Islamists. If our findings are valid, governments' choice of tactics should depend on the type of rebels they are fighting. If the opposition consists mainly of roving jihadists, selective punishment may fail to generate clear incentives for non-rebellion.

The puzzle, then, is this: Islamists have been a small minority of Russia's opponents in the Caucasus, but 63 percent of the government's violence since 2000 has been indiscriminate rather than selective. Why has Russia favored such suboptimal counterinsurgency tactics? One reason may be the relative cost. Targeted killings are logistically cheap, but informationally intensive. "Mop-ups" are logistically intensive but informationally cheap, allowing the government to substitute abundant manpower for deficient intelligence. Yet even in settings where the two practices were equally likely to occur, selective violence had a consistently suppressive effect only against nationalists.

A simpler explanation may be that Russia does not know who the perpetrators of violence are, or more cynically, does not care. After two decades of conflict, Moscow has convinced itself and large swaths of its public that (1) Islamists are respon- 
sible for most violence; (2) Islamists do not behave like rational actors; and (3) therefore it makes little sense to devote resources to dissuade them from violence.

This study challenges these perceptions. The dividing line between Islamist and nationalist groups is indeed murky, particularly in the Caucasus, where the two overlap in mission and personnel. Yet it is possible to distinguish empirically the violence perpetrated by these groups, using multiple operational definitions to account for uncertainty over the dividing lines. The data show that Islamic insurgents are responsible for just 3 to 19 percent of non-state violence in the region, and the military conduct of Islamist and nationalists groups is more similar than not.

Finally, although traditional tools of coercion are indeed less effective in reducing Salafi-Jihadi violence, we believe it is possible to explain this trend without departing from the rational actor model. We hypothesized that the structure of Islamists' support base, particularly their ability to attract external resources, may enable them to maintain operations where the population faces heavy penalties for cooperation. The empirical implications of this mechanism are consistent with our results, although a more rigorous test would require data on support flows to rebel units, and government efforts to interdict them - data that do not currently exist. Given that both nationalist and Islamist violence, and increasingly a combination of the two, are likely to continue throughout the world, we hope that our analysis provides an important initial step in understanding whether and how religion shapes the conduct of war, and what strategies governments should adopt to counter the violence. 


\section{APPENDIX: A FOUR-TIERED TYPOLOGY OF VIOLENCE}

We used an actor-tactic-target framework to construct four definitions of Islamist violence: expansive, intermediate, limited, and target-based. The following section outlines these categories, while the online appendix includes illustrative examples.

\section{Expansive}

An act of Islamist violence must involve at least one of the following actors: IMMB, ChRI Sharia Guard, Arab Mujahideen, Caucasus Front, Caucasus Emirate, and any unknown or unidentified non-state armed group (NVF) with explicitly Islamist objectives, which used Islamic rhetoric during or after the incident, or was characterized by government or media sources as "Wahhabi"; any of the followings tactics: bombing (vehicle-borne, roadside, suicide), light arms fire, rocketpropelled grenade attack, terrorist attack, ambush, hit-and-run, drive-by shooting, ethnic cleansing, hostage-taking, abduction, kidnapping (hereafter "guerrilla tactics"); against any civilian or government target. This category also includes any suicide terrorist attack without a claim of responsibility.

An act of nationalist violence must involve at least one of the following actors: ChRI Armed Forces, or any unknown or unidentified non-state armed group (NVF) that proclaimed separatist or nationalist objectives, and was not reported to have used Islamic rhetoric during or after the incident; any tactic listed above under "guerrilla tactics;" against any civilian or government target.

\section{Intermediate}

An act of Islamist violence must involve at least one of the following actors: IMMB, ChRI Sharia Guard, Arab Mujahideen, Caucasus Front, Caucasus Emirate; any "guerrilla tactics"; against civilian or government targets.

An act of nationalist violence must involve any of the following actors: ChRI Armed Forces, or any unknown or unidentified NVF that proclaimed separatist or nationalist objectives, and was not reported to have used Islamic rhetoric during or after the incident; any "guerrilla tactics"; against civilian or government targets. 


\section{Limited}

An act of Islamist violence must involve at least one of the following actors: IMMB, Arab Mujahideen (post-2006),33 Caucasus Front, Caucasus Emirate; any "guerrilla tactics"; against civilian or government targets.

An act of nationalist violence must involve at least one of the following actors: ChRI Armed Forces, ChRI Sharia Guard, Arab Mujahideen (pre-2006), or any unknown or unidentified NVF that proclaimed separatist or nationalist objectives, and was not reported to have used religious rhetoric during or after the incident; any "guerrilla tactics"; against civilian or government targets.

\section{Target-based}

An act of Islamist violence must involve at least one of the following actors: IMMB, ChRI Sharia Guard, Arab Mujahideen, Caucasus Front, Caucasus Emirate, or any unknown or unidentified NVF that proclaimed Islamist objectives, used Salafist rhetoric during or after the incident, or was described by government or media sources as "Wahhabi"; any "guerrilla tactics"; against any target of "religious significance" (i.e. alcohol-selling business, bar, liquor store, non-halal restaurant, bathhouse, strip club, pornography shop, brothel, Sufi mosque, clergy, worshipper, Christian, Jew, church, synagogue, denominational cemetery, shrine or holy site).

An act of nationalist violence must involve any of the following actors: ChRI Armed Forces, or any unknown or unidentified NVF that proclaimed separatist or nationalist objectives, and was not reported to have used Islamic rhetoric during or after the incident; any "guerrilla tactics"; against civilian or government targets, except those listed as having "religious significance."

33 Prior to 2006, Arab Mujahideen operated under the nominal command of ChRI Armed Forces. After 2006, they began operating under the nominal command of the Caucasus Front. 


\section{REFERENCES}

“Jihad and the Fields." 2013. Sharia and Life. Al Jazeera. 2 August. Television.

"Shamil' Basaev o sobytiyakh v Beslane [Shamil Basaev on the events in Beslan]." 2012. KavkazCenter.com, 1 September.

"Aslan Maskhadov: Voina zakonchitsya togda, kogda uydut te prishel s voynoy [Aslan Maskhadov: The war will end when those who came with war leave].” 2003. Kavkazskiy Uzel, 26 March.

"Bastrykin naschital na Kavkaze poltory tysyachi boevikov [Bastrykin counts 1,500 rebels in the Caucasus]." 2009. Lenta.ru. 20 May. http://lenta.ru/news/2009/05/20/boevicks/ (Accessed 16 October 2014).

"Statistika pohischeniy i ubiystv v Chechne i Ingushetii [Kidnapping and Murder Statistics in Chechnya and Ingushetia]." n.d. Memorial Human Rights Center. http://memo.ru/hr/hotpoints/n-caucas/misc/razr/razr.htm (Accessed January 22, 2014).

"Official Release of the Statement by Amir Dokka Umarov about the Declaration of the Caucasus Emirate." 2007. Press Office of the Amir of the Caucasus Emirate, 7 October.

Anderson, Benedict. 1991. Imagined Communities: Reflections on the Origin and Spread of $\mathrm{Na-}$ tionalism, rev. ed. London: Verso.

Asal, Victor and R. Karl Rethemeyer. 2008. "The nature of the beast: Organizational structures and the lethality of terrorist attacks." The Journal of Politics 70(2): 437-449.

Azam, Jean-Paul. 2005. "Suicide-Bombing as Inter-Generational Investment." Public Choice 122 (12): 177-198.

Barrett, Richard. 2014. Foreign Fighters in Syria. New York, NY: The Soufan Group.

Batuev, Valeriy. 1999. "Shamil Basaev: ya vzyal Islamskiy flag v svoi ruki [Shamil Basaev: I took the Islamic flag into my own hands].” Moskovskiy Komsomolets, 1 March.

Becker, Gary S. 1974. "Crime and punishment: An economic approach.” In Gary S. Becker and William M. Landes, eds. Essays in the Economics of Crime and Punishment, pp. 1-54. UMI, 1974.

Berman, Eli, and David Laitin. 2006. Hard targets: Theory and evidence on suicide attacks. National Bureau of Economic Research, no. w11740.

Berman, Eli, and David D. Laitin. 2008. "Religion, terrorism and public goods: Testing the club model.” Journal of Public Economics 92(10): 1942-1967.

Blattman, Christopher, and Edward Miguel. 2010. "Civil war." Journal of Economic Literature 48(1): 3-57.

Bloom, Mia. 2005. Dying to Kill. New York: Columbia University Press.

Brown, Michael E., Owen R. Cote, Jr., Sean M. Lynn-Jones, and Steven E. Miller, eds. 1997. Nationalism and Ethnic Conflict. Cambridge, MA: MIT Press.

Bueno De Mesquita, Ethan. 2005. "The Quality of Terror.” American Journal of Political Science 49 (3): 515-530.

Caplan, Bryan. 2006. "Terrorism: The relevance of the rational choice model." Public Choice 128: 91-107.

Collier, Paul and Anke Hoeffler. 2004. "Greed and grievance in civil war." Oxford economic papers 56 (4): 563-595. 
Fearon, James and David Laitin. 2003. "Ethnicity, insurgency, and civil war." American Political Science Review 97(1): 75-90.

Felter, Joseph and Brian Fishman. 2007. Al-Qa'ida's Foreign Fighters in Iraq: A First Look at the Sinjar Records. West Point, NY: Combating Terrorism Center.

Hassner, Ron. 2003. "To Halve and to Hold: Conflicts over Sacred Space and the Problem of Indivisibility." Security Studies 12 (4, Summer): 1-33.

Hassner, Ron. 2011. "Sacred Time and Conflict Initiation." Security Studies 20(4): 491-520.

Hassner, Ron and Michael C. Horowitz. 2010. "Correspondence: Debating the Role of Religion in War.” International Security 35 (1, Summer): 201-208.

Hegghammer, Thomas. 2010/2011. "The Rise of Muslim Foreign Fighters: Islam and the Globalization of Jihad.” International Security 35 (3, Winter): 53-94.

Hegghammer, Thomas. 2013. "Should I Stay or Should I Go? Explaining Variation in Western Jihadists' Choice between Domestic and Foreign Fighting.” American Political Science Review 107 (1): $1-15$.

Hoffman, Bruce. 1998. Inside Terrorism. New York: Columbia University Press.

Hoffman, Bruce. 2006. "From the War on Terror to Global Counterinsurgency." Current History (December): 423-429.

Horowitz, Michael C. 2009. "Long Time Going: Religion and the Duration of Crusading." International Security 34 (2, Fall): 162-193.

Iannaccone, Laurence R., and Eli Berman. 2006. "Religious extremism: The good, the bad, and the deadly." Public Choice 128: 109-129.

International Crisis Group. 2012. “Tentative Jihad: Syria's Fundamentalist Opposition.” Middle East Report (131).

International Crisis Group. 2013. "Mali: Security, Dialogue and Meaningful Reform.” Africa Report (201).

International Institute of Strategic Studies. 2002. "Table 6 Selected Non-State Armed Groups." The Military Balance 102(1): 224-231.

Juergensmeyer, Mark. 2000. Terror in the Mind of God: The Global Rise of Religious Violence. Berkeley: University of California Press.

Kalyvas, Stathis. 2006. The Logic of Violence in Civil War. New York: Cambridge University Press.

Lake, David A. and Donald S. Rothchild. 1998. The International Spread of Ethnic Conflict: Fear, Diffusion, and Escalation. Princeton, NJ: Princeton University Press.

Long, Austin. 2008. “The Anbar Awakening." Survival 50 (2, April/May): 67-94.

Lyall, Jason. 2010. "Are Coethnics More Effective Counterinsurgents? Evidence from the Second Chechen War." American Political Science Review 104 (1): 1-20.

Malashenko, Aleksey. 2001. Islamskiye orientiry Severnogo Kavkaza [Islamic Reference Points of the North Caucasus]. Moscow: Gendal'f.

Markedonov, Sergey. 2006. "Terrorizm na rossiyskom Severnom Kavkaze: vyzov i poisk otveta [Terrorism in Russia's North Caucasus: Challenge and Search for Answers].” Politicheskij klass 6: $37-43$.

Mason, T. David and Dale A. Krane. 1989. "The Political Economy of Death Squads: Toward a Theory of the Impact of State-Sanctioned Terror.” International Studies Quarterly 33 (2): 175-198.

Miller, Greg. 2014. "Airstrikes against Islamic State have not affected flow of foreign fighters to Syria.” The Washington Post, 30 October. 
Moghadam, Assaf. 2008. The Globalization of Martyrdom: Al Qaeda, Salafi Jihad, and the Diffusion of Suicide Attacks. Baltimore: Johns Hopkins University Press.

Moghadam, Assaf. 2008/o9. "Motives for Martyrdom: Al-Qaida, Salafi Jihad, and the Spread of Suicide Attacks." International Security 33 (3, Winter): 46-78.

O'Loughlin, John, Edward Holland, and Frank Witmer. 2011. "The Changing Geography of Violence in the North Caucasus of Russia, 1999-2011: Regional Trends and Local Dynamics in Dagestan, Ingushetia and Kabardino-Balkaria." Eurasian Geography and Economics 52 (5): 596-630.

Pape, Robert A. 2005. Dying to Win: The Strategic Logic of Suicide Terrorism. New York: Random House.

Sageman, Marc. 2004. Understanding Terror Networks. Philadelphia: University of Pennsylvania Press.

Sambanis, Nicholas. 2001. "Do ethnic and nonethnic civil wars have the same causes? A theoretical and empirical inquiry (Part 1).” Journal of Conflict Resolution 45 (3): 259-282.

Schelling, Thomas. 1966. Arms and influence. New Haven: Yale University Press.

Stern, Jessica. 2003. Terror in the Name of God: Why Religious Militants Kill. New York: Ecco.

Toft, Monica Duffy. 2007. "Getting Religion? The Puzzling Case of Islam and Civil War," International Security, 31 (4, Spring): 97-131.

Toft, Monica Duffy. 2003. The Geography of Ethnic Violence: Identity, Interests and the Indivisibility of Territory. Princeton, New Jersey: Princeton University Press.

Toft, Monica Duffy, and Yuri M. Zhukov. 2012. "Denial and punishment in the North Caucasus Evaluating the effectiveness of coercive counter-insurgency." Journal of Peace Research 49 (6): 785-800.

Varshney, Ashutosh. 2003. "Nationalism, Ethnic Conflict, and Rationality." Perspectives on Politics 1 (1): 85-99.

Weinstein, Jeremy M. 2007. Inside Rebellion. New York: Cambridge University Press.

White, Jeffrey and Brooke Neuman. 2005. "Iraq's Sunnis Play the Election Card." Washington Institute for Near East Policy (1062, December 13).

Wintrobe, Ronald. 2003. "Can suicide bombers be rational." Unpublished manuscript, University of Western Ontario.

Yarlykapov, Ahmet. 2006. "Narodnyi Islam' i musul'manskaya molodezh tsentral'nogo i severnozapadnogo kavkaza ['People's Islam' and the Muslim Youth of Central and North-West Caucasus]." Etnograficheskoye obozreniye 2 (April): 59-74.

Zaitsev, Vadim. 2011. "Naemniki v Chechnye [Mercenaries in Chechnya]." Kommersant, 21 March.

Zhukov, Yuri M. 2012. "Roads and the diffusion of insurgent violence: The logistics of conflict in Russia's North Caucasus." Political Geography 31 (3): 144-156. 


\section{TABLES}

Table 1: Breakdown of North Caucasus violence by type, 2000-2012.

\begin{tabular}{l|llll} 
Definition & Islamist & Nationalist & Other & Total \\
\hline Expansive & $1772(18.8 \%)$ & $6260(66.7 \%)$ & $1373(14.6 \%)$ & $9405(100 \%)$ \\
Intermediate & $1570(16.7 \%)$ & $6292(66.9 \%)$ & $1543(16.4 \%)$ & $9405(100 \%)$ \\
Limited & $813(8.6 \%)$ & $7049(74.9 \%)$ & $1543(16.4 \%)$ & $9405(100 \%)$ \\
Target-based & $241(2.6 \%)$ & $7004(74.5 \%)$ & $2160(23 \%)$ & $9405(100 \%)$
\end{tabular}

Notes: Numbers represent counts of insurgent attacks of each type (columns), according to the four definitions of "Islamist" violence (rows). Percentages in parentheses.

\section{Table 2: Mean distance from nearest previous attack.}

\begin{tabular}{l|ll} 
Definition & Islamist & Nationalist \\
\hline Expanded & $125.66(112.3,140.4)$ & $51.99(47.5,56.7)$ \\
Intermediate & $164.72(147.5,184.9)$ & $51.71(47.2,56.5)$ \\
Limited & $496.85(433.2,566.5)$ & $51.04(46.7,55.6)$ \\
Target-based & $493.63(423.1,570.2)$ & $50.11(45.7,54.7)$
\end{tabular}

Notes: Numbers represent the average distance, in kilometers, from the location of an incident of insurgent violence (Islamist or nationalist) to the nearest location where an attack of the same type occurred in the previous week. Bootstrapped 95\% confidence intervals in parentheses.

Table 3: Violence increase on weeks with high global jihadist activity.

\begin{tabular}{l|ll} 
Definition & Islamist & Nationalist \\
\hline Expanded & $+77.84 \%(+52.7 \%,+105.1 \%)$ & $+29.57 \%(+18.8 \%,+41.4 \%)$ \\
Intermediate & $+92.87 \%(+66.0 \%,+122.8 \%)$ & $+29.20 \%(+18.0 \%,+41.7 \%)$ \\
Limited & $+87.70 \%(+53.6 \%,+129.5 \%)$ & $+35.24 \%(+24.1 \%,+47.4 \%)$ \\
Target-based & $+83.53 \%(+35.8 \%,+156.1 \%)$ & $+35.35 \%(+24.7 \%,+46.8 \%)$
\end{tabular}

Notes: Numbers represent percent change in the number of local insurgent attacks (Islamist or nationalist) in weeks with higher-than-average levels of global suicide terrorism, relative to weeks with lower-than-average levels of global terrorism. Bootstrapped 95\% confidence intervals in parentheses. 
Table 4: Violence increase on weeks with Muslim holidays.

\begin{tabular}{l|ll} 
Definition & Islamist & Nationalist \\
\hline Expanded & $+10.59 \%(-7.8 \%,+31.9 \%)$ & $+4.16 \%(-6.6 \%,+15.9 \%)$ \\
Intermediate & $+15.32 \%(-5.1 \%,+39.0 \%)$ & $+4.21 \%(-6.8 \%,+15.5 \%)$ \\
Limited & $+25.67 \%(-5.3 \%,+60.4 \%)$ & $+4.26 \%(-6.3 \%,+15.7 \%)$ \\
Target-based & $+73.16 \%(+20.6 \%,+139 \%)$ & $+3.27 \%(-7.1 \%,+14.8 \%)$
\end{tabular}

Notes: Numbers represent percent change in the number of local insurgent attacks (Islamist or nationalist) on weeks with Muslim holidays, relative to no Muslim holidays. Bootstrapped 95\% confidence intervals in parentheses.

Table 5: Violence decrease following selective government violence.

\begin{tabular}{l|ll} 
Definition & Islamist & Nationalist \\
\hline Expanded & $-43.69 \%(-48.2 \%,-38.5 \%)$ & $-55.30 \%(-58.2 \%,-52.3 \%)$ \\
Intermediate & $-44.35 \%(-49.0 \%,-39.3 \%)$ & $-55.26 \%(-58.3 \%,-52.4 \%)$ \\
Limited & $-42.28 \%(-48.3 \%,-35.5 \%)$ & $-54.41 \%(-57.5 \%,-51.5 \%)$ \\
Target-based & $-37.39 \%(-47.3 \%,-26.0 \%)$ & $-54.58 \%(-57.5 \%,-51.8 \%)$
\end{tabular}

Notes: Numbers represent percent change in insurgent violence (Islamist or nationalist) in the twelve weeks following the use of selective counterinsurgency tactics, relative to indiscriminate tactics. Lower numbers indicate greater counterinsurgency effectiveness. Bootstrapped 95\% confidence intervals in parentheses. 


\section{FIGURE CAPTIONS AND NOTES}

Figure 1: Four-tiered typology of Islamist violence.

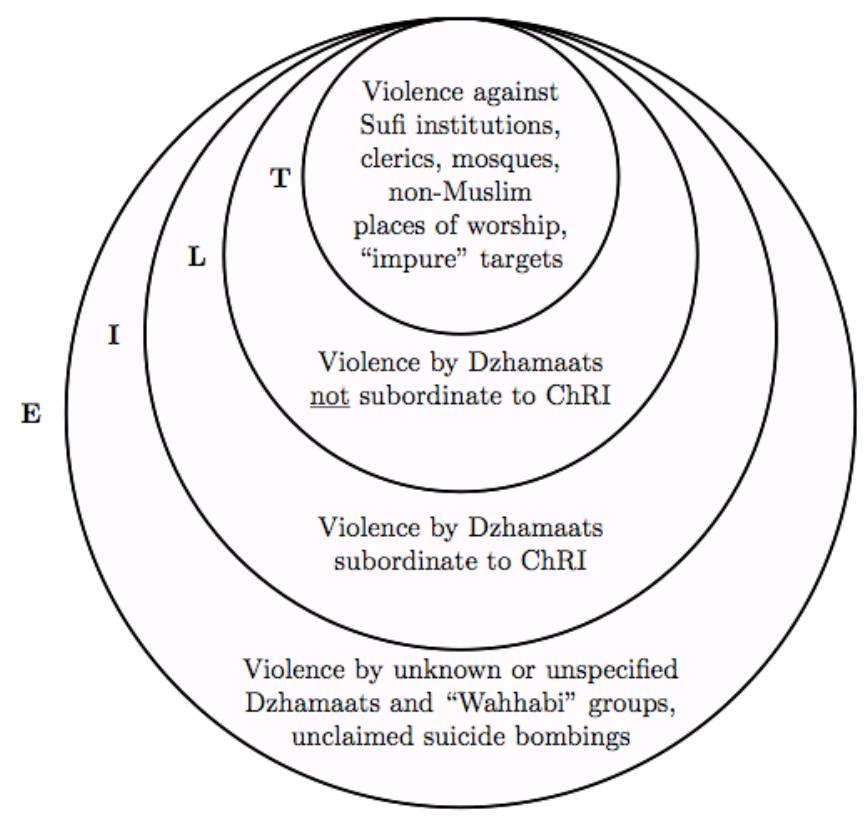

Notes: E: expanded definition. I: intermediate definition. L: limited definition. T: target-based definition. 
Figure 2: Islamist and nationalist violence in the North Caucasus.

a) Expanded definition

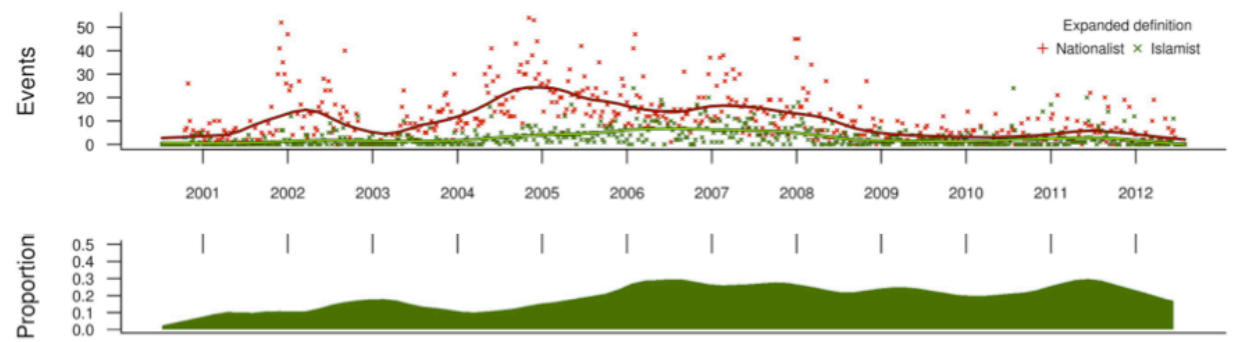

b) Intermediate definition
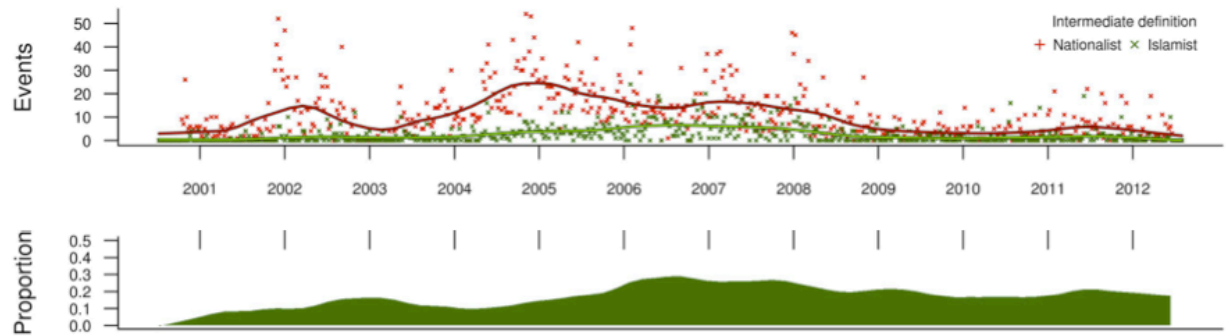

c) Limited definition

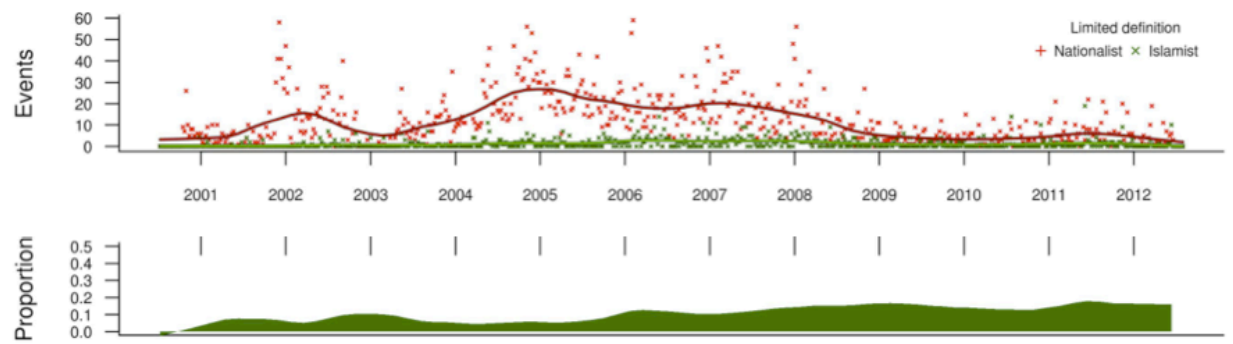

d) Target-based definition
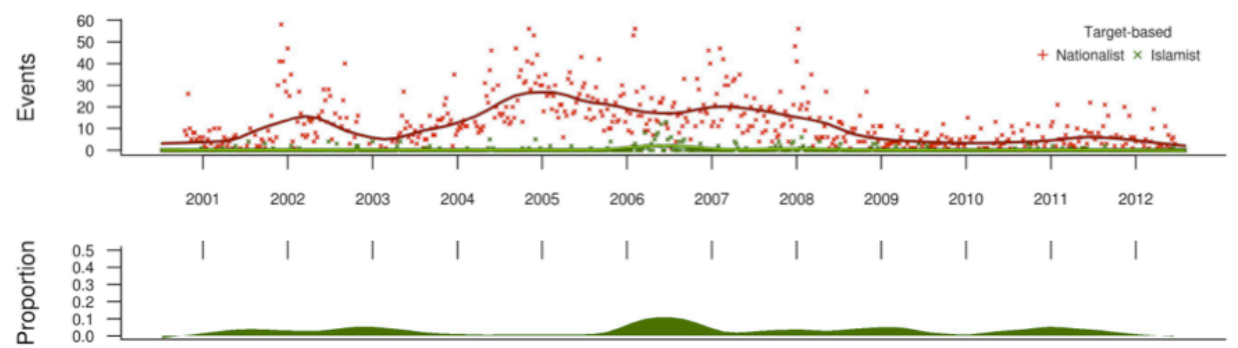

Notes: Red crosses and green x's are incidents of nationalist and Islamist violence per week. Red and green lines are six-month moving averages. Shaded green area is Islamist violence as a share of all violence (six-month moving average). 
Figure 3. Distribution of nationalist and Islamist insurgent attacks.

a) Location of attacks

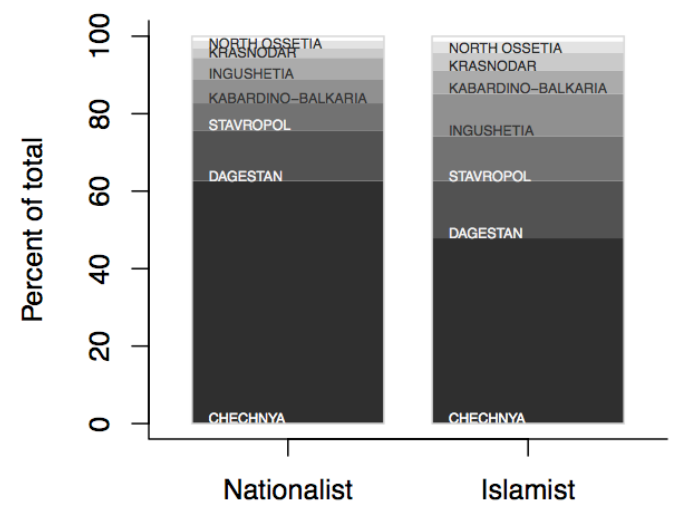

b) Majority ethnicity of attacked village

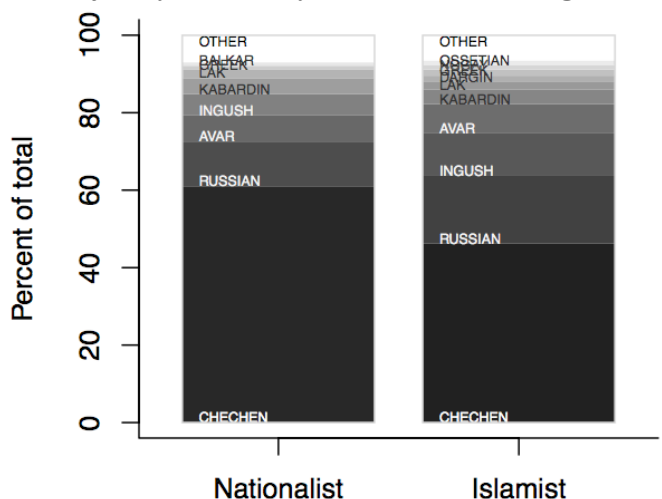

Notes: Bars represent percentage of attacks by each type of insurgent, which took place in a) each North Caucasus republic or region, and b) villages dominated by a specific ethnic group. Intermediate definition of Islamist violence used. 
Figure 4: Empirical determinants of insurgent violence.

\begin{tabular}{|c|c|c|}
\hline Variable & Counterfactual & Percent change in probability of attack \\
\hline $\begin{array}{l}\text { Global suicide } \\
\text { terrorism }\end{array}$ & $\begin{array}{l}\text { An increase from o }\left(1^{\text {st }} \text { percentile }\right) \\
\text { to } 12\left(99^{\text {th }} \text { percentile }\right) \text { global suicide } \\
\text { terrorist attacks in previous week }\end{array}$ & 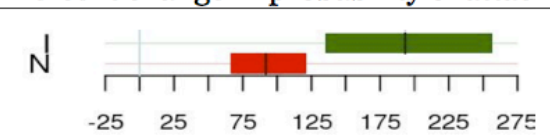 \\
\hline $\begin{array}{l}\text { Muslim } \\
\text { holidays }\end{array}$ & $\begin{array}{l}\text { A change in calendar date from } \\
\text { non-holiday to a Muslim holiday }\end{array}$ & \begin{tabular}{ccc|cc} 
& & & \multicolumn{1}{|c|}{$\mid$} \\
& 1 & $\mid$ & 1 & \\
-50 & -25 & 0 & 25 & 50
\end{tabular} \\
\hline $\begin{array}{l}\text { Nationalist } \\
\text { holidays }\end{array}$ & $\begin{array}{l}\text { A change in calendar date from } \\
\text { non-holiday to a ChRI holiday }\end{array}$ & 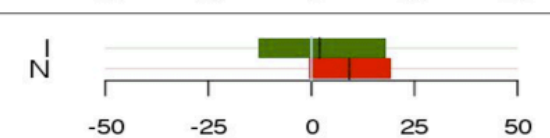 \\
\hline $\begin{array}{l}\text { Number of } \\
\text { neighboring } \\
\text { insurgent } \\
\text { attacks }\end{array}$ & $\begin{array}{l}\text { An increase from o }\left(1^{\text {st }} \text { percentile }\right) \\
\text { to } 8\left(99^{\text {th }} \text { percentile }\right) \text { attacks in } \\
\text { neighboring districts in previous } \\
\text { week }\end{array}$ & 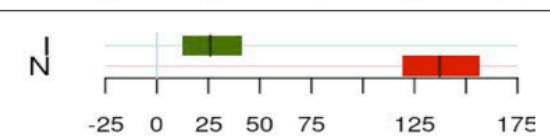 \\
\hline $\begin{array}{l}\text { Rough terrain } \\
\text { (elevation) }\end{array}$ & $\begin{array}{l}\text { An increase from }-15\left(1^{\text {st }} \text { percentile }\right) \\
\text { to } 1951\left(99^{\text {th }} \text { percentile }\right) \text { meters }\end{array}$ & 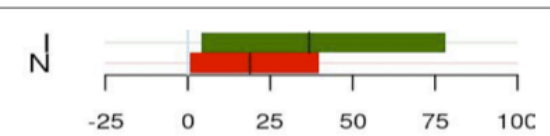 \\
\hline $\begin{array}{l}\text { Population } \\
\text { density }\end{array}$ & $\begin{array}{l}\text { An increase from } 10\left(1^{\text {st }} \text { percentile }\right) \\
\text { to } 9446\left(99^{\text {th }} \text { percentile }\right) \text { residents } \\
\text { per square } \mathrm{km}\end{array}$ & 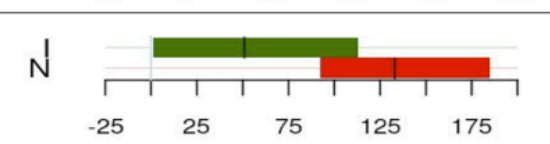 \\
\hline $\begin{array}{l}\text { Military } \\
\text { presence }\end{array}$ & $\begin{array}{l}\text { An increase from o }\left(1^{\text {st }} \text { percentile }\right) \\
\text { to } 145\left(99^{\text {th }} \text { percentile }\right) \mathrm{km} \text { to } \\
\text { nearest military base }\end{array}$ & 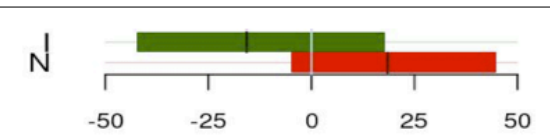 \\
\hline Refugees & $\begin{array}{l}\text { An increase from } 3\left(1^{\text {st }} \text { percentile) to }\right. \\
201\left(99^{\text {th }} \text { percentile }\right) \mathrm{km} \text { to nearest } \\
\text { refugee camp }\end{array}$ & 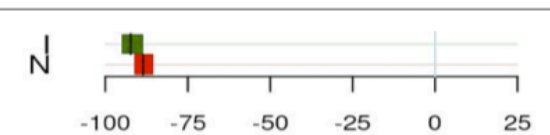 \\
\hline $\begin{array}{l}\text { Distance to } \\
\text { intl. border } \\
\text { crossing }\end{array}$ & $\begin{array}{l}\text { An increase from } 28\left(1^{\text {st }} \text { percentile }\right) \\
\text { to } 500\left(99^{\text {th }} \text { percentile }\right) \mathrm{km} \text { to } \\
\text { nearest international border } \\
\text { crossing }\end{array}$ & 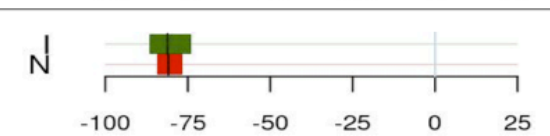 \\
\hline $\begin{array}{l}\text { Percent fluent } \\
\text { Russian } \\
\text { speakers }\end{array}$ & $\begin{array}{l}\text { An increase from } 51\left(1^{\text {st }} \text { percentile }\right) \\
\text { to } 95\left(99^{\text {th }} \text { percentile }\right) \text { percent } \\
\text { Russian-speaking }\end{array}$ & 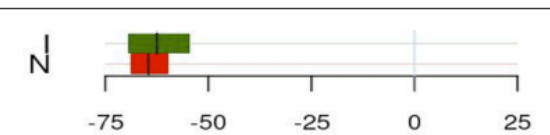 \\
\hline $\begin{array}{l}\text { Deportation } \\
\text { in } 1944\end{array}$ & $\begin{array}{l}\text { An increase from o }\left(1^{\text {st }} \text { percentile }\right) \\
\text { to } 100\left(99^{\text {th }} \text { percentile) percent }\right. \\
\text { deported }\end{array}$ & 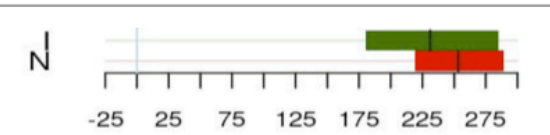 \\
\hline Forest & $\begin{array}{l}\text { An increase from o }\left(1^{\text {st }} \text { percentile }\right) \\
\text { to } 91\left(99^{\text {th }} \text { percentile }\right) \text { percent forest } \\
\text { cover }\end{array}$ & 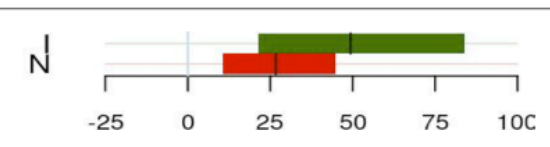 \\
\hline
\end{tabular}

Notes: I: Islamist, N: nationalist. Horizontal bars are 95\% confidence intervals. 
Figure 5: Effect of selective counterinsurgency tactics on insurgent violence.

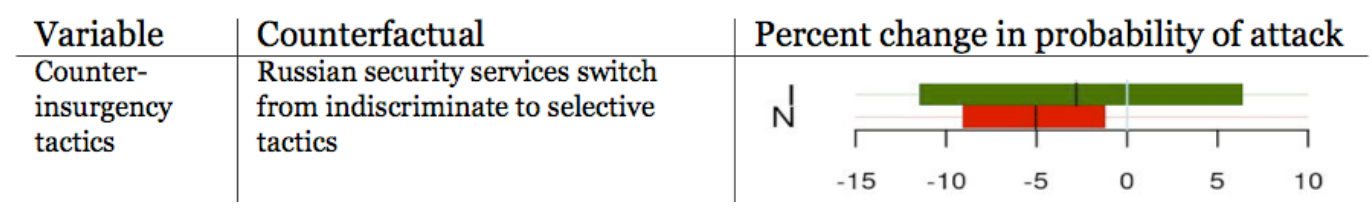

Notes: I: Islamist, N: nationalist. Coarsened exact matching results reported. Horizontal bars are 95\% confidence intervals.

Figure 6: Effect of local counterinsurgency agency on insurgent violence.

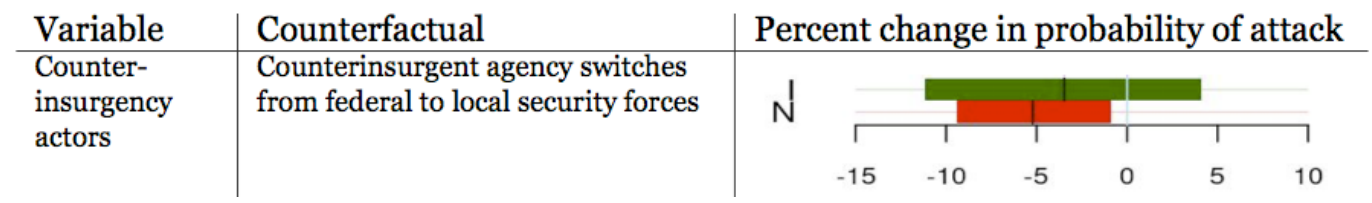

Notes: I: Islamist, N: nationalist. Propensity score matching results reported. Horizontal bars are $95 \%$ confidence intervals. 